\title{
Mechanistic studies on the metal-free decarboxylativecoupling reaction for synthesis of propargylamines by NMR
}

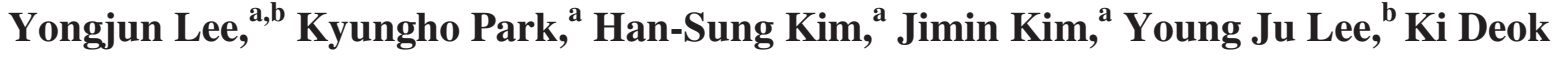 \\ Park, ${ }^{* b}$ Jonghoon Oh, ${ }^{* a}$ and Sunwoo Lee ${ }^{*^{a}}$ \\ ${ }^{a}$ Department of Chemistry, Chonnam National University, Gwangju, 61186, Republic of Korea \\ ${ }^{b}$ Gwangju Center, Korea Basic Science Institute, Gwangju 61186, Republic of Korea \\ E-mail:kdpark@kbsi.re.kr,jhoh@chonnam.ac.kr,sunwoo@chonnam.ac.kr
}

DOI: http://dx.doi.org/10.3998/ark.5550190.p009.632

\begin{abstract}
Metal-free decarboxylative coupling reaction of phenylpropiolic acid, paraformaldehyde, and morpholine was monitored by NMR spectroscopy $\left({ }^{1} \mathrm{H},{ }^{13} \mathrm{C}\right.$ NMR, NOE, DOSY, COSY HMBC, and HSQC). Hemiaminal and bisaminal were obtained from the reaction with paraformaldehyde and morpholine. The resulting hemiaminal was more reactive than the corresponding bisaminal in the reaction with phenylpropiolic acid. The decarboxylative coupling with hemiaminal and phenylpropiolic acid may be the major pathway, producing the desired phenylpropargylamine.
\end{abstract}

Keywords: Mechanism, NMR, decarboxylative coupling, propiolic acids, propargylamines

\section{Introduction}

In recent years metal-catalyzed decarboxylative coupling reactions have received much attention in organic chemistry. ${ }^{1,2}$ As the starting materials, carboxylic acids, are stable and environmentally friendly because they release nontoxic carbon dioxide as the by-product in the coupling reactions. The decarboxylative coupling reaction with aromatic carboxylic acids has been developed since Goossen first reported Pd-catalyzed decarboxylative coupling in $2007 .{ }^{3} \mathrm{We}$ first reported the Pd-catalyzed decarboxylative coupling of alkynylcarboxylic acids in 2008 ., Since then, several related methods have been independently developed by us and other groups. ${ }^{6-16}$ The decarboxylative coupling of alkynylcarboxylic acids showed a similar reaction pattern to the Sonogashira reaction of terminal alkynes. Therefore, alkynylcarboxylic acids have been used as the surrogates of terminal alkynes in the coupling reactions and three-component reactions. ${ }^{17-21}$ In particular, propiolic acid has been widely used as a source of acetylene because it can be easily handled and stored. 
Propargylamine is one of the important building blocks in the synthesis of heterocyclic molecules containing a nitrogen atom. ${ }^{22-29}$ Several synthetic methods have been developed. ${ }^{30-33}$ The metal-catalyzed three-component reaction of an alkyne, amine, and aldehyde is one of the frequently used methods because it is simple and straightforward; $\mathrm{Zn}, \mathrm{Rh}, \mathrm{Fe}, \mathrm{In}, \mathrm{Cu}, \mathrm{Co}, \mathrm{Au}$, and $\mathrm{Ag}$, for examples, have been used as metal catalysts. ${ }^{34-45}$

Recently, we reported the $\mathrm{Cu}$-catalyzed three-component reaction of arylalkynylcarboxylic acids with aldehydes and amines to provide the corresponding propargyl amines. ${ }^{46}$ This threecomponent coupling provides the desired products even in the absence of metal catalysts when paraformaldehyde is used. ${ }^{47}$ This report was the first example of the metal-free decarboxylative coupling reaction of alkynylcarboxylic acids. In continuation of our efforts to develop decarboxylative coupling reactions and investigate their reaction pathways, a systematic study was conducted on the mechanism of metal-free synthesis of propargylamines. Herein, we report NMR studies on the reaction pathways to the decarboxylative coupling with phenylpropiolic acid (PPA), paraformaldehyde, and amine (morpholine).

\section{Results and Discussion}

In the metal-free three-component reaction, we expect that the formation of an aldimine is the initial reaction step. ${ }^{48,49}$ When formaldehyde and morpholine were reacted at $25{ }^{\circ} \mathrm{C}$ in $\mathrm{CD}_{3} \mathrm{CN}$, both hemiaminal (HA) and bisaminal (BA) were formed in 56 and $44 \%$ yields, respectively, in the reaction mixture as shown by the ${ }^{1} \mathrm{H}$ NMR analysis (Figure 1a and Table 1). The experiment was carried out without any drying process for the reagents. All the peaks were assigned by 2D NMR analysis (see Supplementary Material, Figure S1). The singlet peaks of the methylene protons in HA and BA appeared at 4.09 and $2.86 \mathrm{ppm}$, respectively, in the ${ }^{1} \mathrm{H}$ NMR spectra. When the amount of morpholine was doubled, and the ratio of paraformaldehyde to morpholine was $1: 2$, only BA was observed in the ${ }^{1} \mathrm{H}$ NMR spectrum of the reaction mixture. When the temperature was increased to $65{ }^{\circ} \mathrm{C}, \mathbf{H A}$ and $\mathbf{B A}$ reached the equilibrium state $(\mathbf{H A}=60 \%$ and $\mathbf{B A}=40 \%)$.

We added an equal amount of phenylpropiolic acid (PPA) into this resulting mixture and monitored the progress of the reaction by ${ }^{1} \mathrm{H}$ and ${ }^{13} \mathrm{C}$ NMR (Figure 2). Interestingly, the desired product, phenylpropargylamine (PGA), was formed in $40 \%$ yield in 10 min after adding the PPA. However, there was no further increase in this product after a further $24 \mathrm{~h}$ at room temperature. As shown in Table 2, we assigned all the peaks using 2D NMR analysis (COSY, HSQC, and HMBC) (see Supporting Information, Figure S2). All the peaks of free HA and BA in the mixture with PPA shifted to high frequency value in the ${ }^{1} \mathrm{H}$ NMR spectra. This might result from the interactions with PPA through hydrogen bonding. We propose their intermediate structures as $\mathbf{A}$ and $\mathbf{B}$ (Figure 3), in which the morpholine moiety is close to the phenyl ring of PPA, because NOE effect was observed between the phenyl protons of PPA and $\mathrm{H}_{\mathrm{b}}$ of $\mathbf{H A}$ and BA. 
(a) ${ }^{1} \mathrm{H}$ NMR

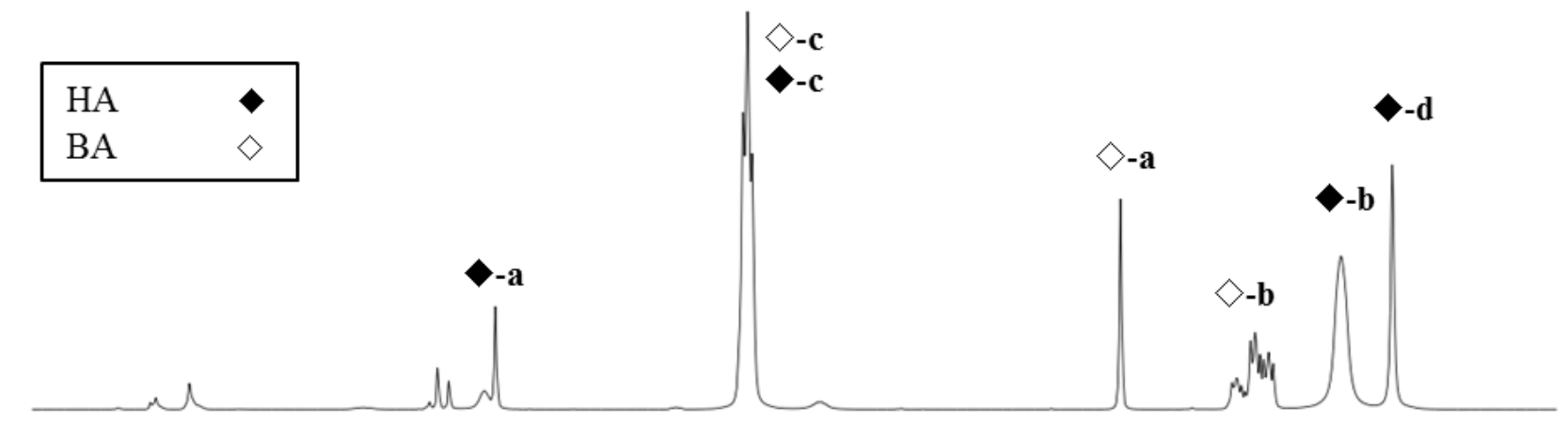

$\begin{array}{llllllllllllllllllllllllllllllllllllllll}5.0 & 4.9 & 4.8 & 4.7 & 4.6 & 4.5 & 4.4 & 4.3 & 4.2 & 4.1 & 4.0 & 3.9 & 3.8 & 3.7 & 3.6 & 3.5 & 3.4 & 3.3 & 3.2 & 3.1 & 3.0 & 2.9 & 2.8 & 2.7 & 2.6 & 2.5 & 2.4 & 2.3 & 2.2 & 2.1\end{array}$

(b) ${ }^{13} \mathrm{C}$ NMR
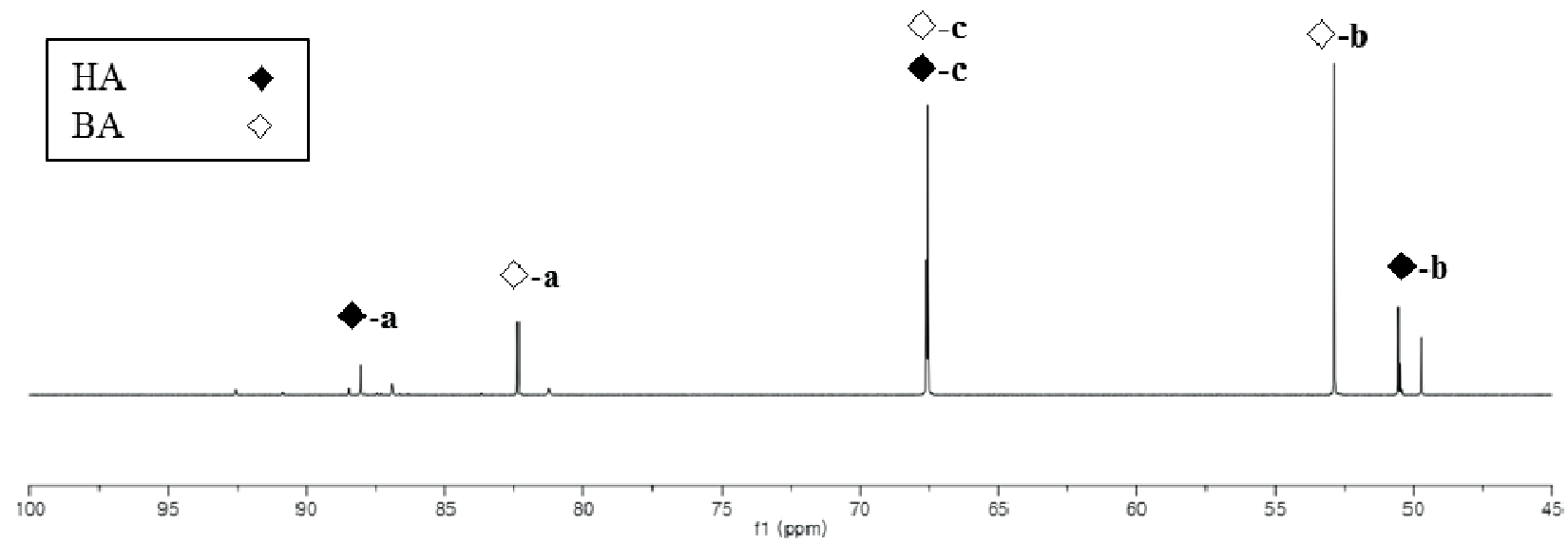

Figure 1. NMR spectra of $\mathbf{H A}$ and $\mathbf{B A}$ in $\mathrm{CD}_{3} \mathrm{CN}$.

Table 1. Assignment of ${ }^{1} \mathrm{H}$ and ${ }^{13} \mathrm{C}$ NMR of $\mathbf{H A}$ and $\mathbf{B} \mathbf{A}^{\mathrm{a}}$

\begin{tabular}{ccc}
\hline Aminal $^{\mathrm{a}}$ & ${ }^{1} \mathrm{H} \mathrm{NMR}\left(\mathrm{CD}_{3} \mathrm{CN}, \mathrm{ppm}\right)$ & ${ }^{13} \mathrm{C} \mathrm{NMR}\left(\mathrm{CD}_{3} \mathrm{CN}, \mathrm{ppm}\right)$ \\
\hline HA & $\delta 4.09\left(\mathrm{~s}, \mathrm{H}_{\mathrm{a}}\right), 3.59\left(\mathrm{~m}, \mathrm{H}_{\mathrm{c}}\right), 2.60\left(\mathrm{~m}, \mathrm{H}_{\mathrm{b}}\right)$, & $\delta 88.0\left(\mathrm{C}_{\mathrm{a}}\right), 67.6\left(\mathrm{C}_{\mathrm{c}}\right), 50.5\left(\mathrm{C}_{\mathrm{b}}\right)$ \\
& $2.26\left(\mathrm{~s}, \mathrm{H}_{\mathrm{d}}\right)$ & \\
BA & $\delta 3.59\left(\mathrm{~m}, \mathrm{H}_{\mathrm{c}}\right), 2.86\left(\mathrm{~s}, \mathrm{H}_{\mathrm{a}}\right), 2.43\left(\mathrm{t}, \mathrm{H}_{\mathrm{b}}\right)$ & $\delta 82.4\left(\mathrm{C}_{\mathrm{a}}\right), 67.6\left(\mathrm{C}_{\mathrm{c}}\right), 52.8\left(\mathrm{C}_{\mathrm{b}}\right)$ \\
\hline
\end{tabular}

${ }^{a}$ Reaction conditions: paraformaldehyde $(9.0 \mathrm{mg}, 0.3 \mathrm{mmol})$ and morpholine $(26.1 \mathrm{mg}, 0.3$ mmol) were dissolved in $\mathrm{CD}_{3} \mathrm{CN}(0.8 \mathrm{~mL})$ and mixed for $2 \mathrm{~h}$ at $25^{\circ} \mathrm{C}$, and the resulting solution was monitored by NMR (500 MHz). 
(a) ${ }^{1} \mathrm{H}$ NMR

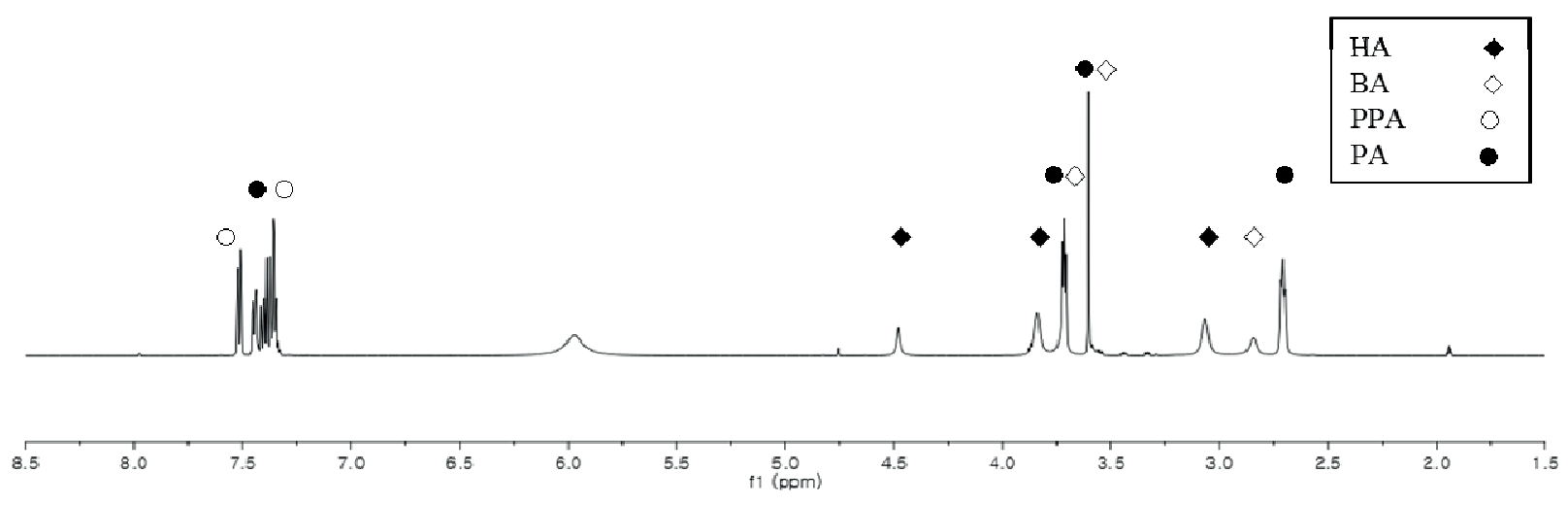

(b) ${ }^{13} \mathrm{C}$ NMR
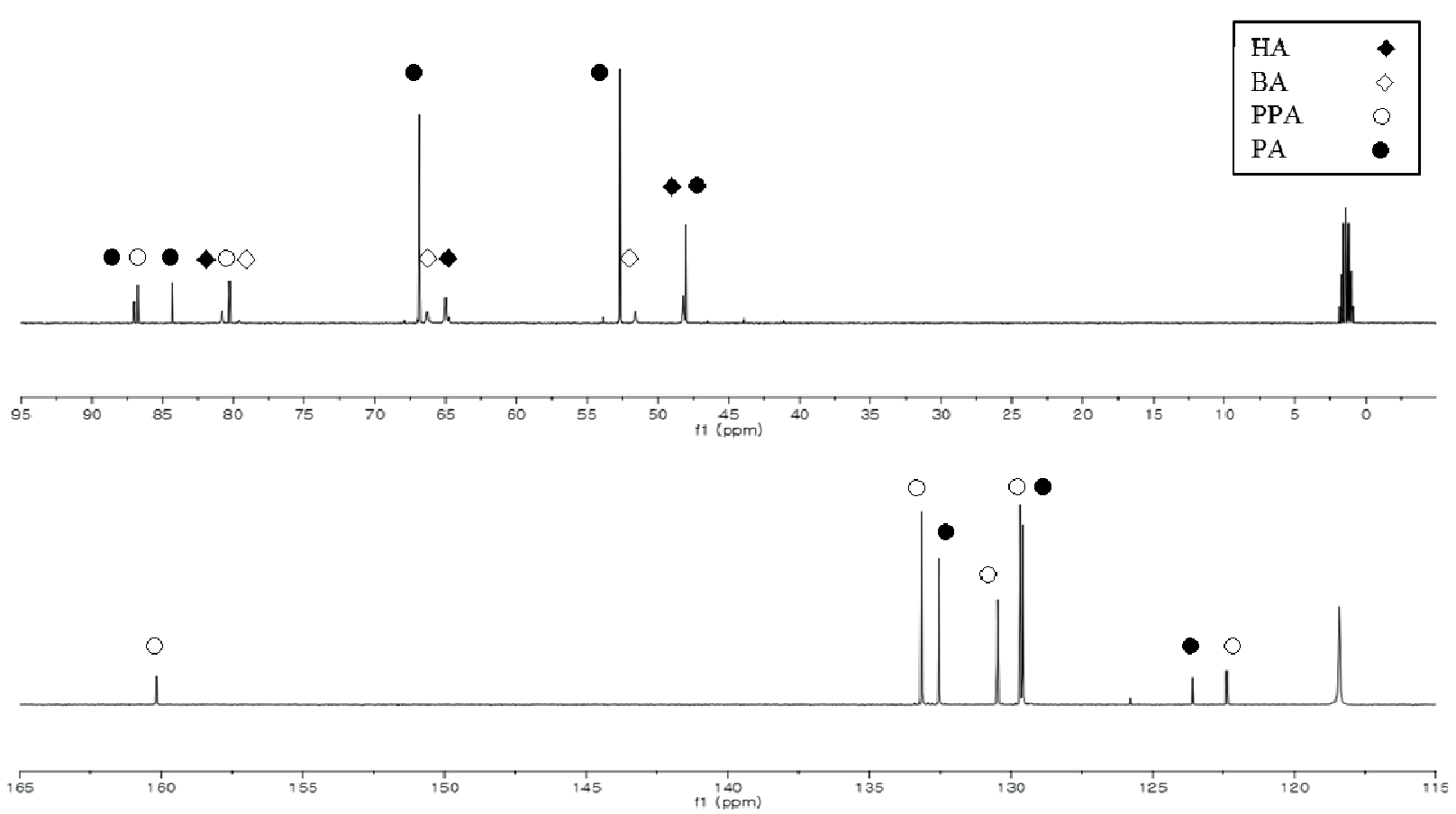

Figure 2. NMR spectra of the reaction mixture of PPA, paraformaldehyde and morpholine in $\mathrm{CD}_{3} \mathrm{CN}$. 
Table 2. Characterization of all the reagents in the reaction mixture ${ }^{\mathrm{a}}$
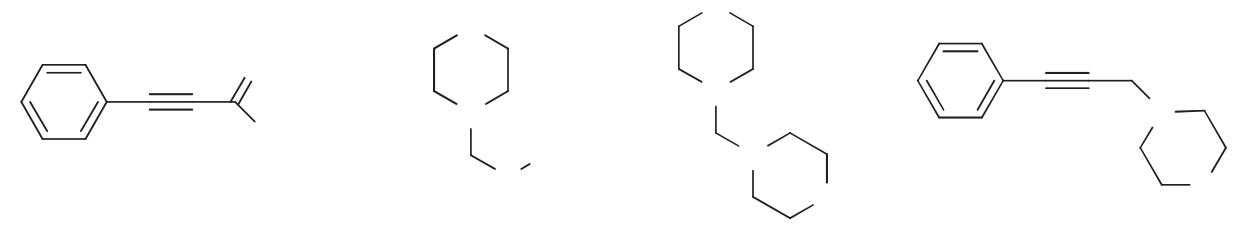

\begin{tabular}{|c|c|c|}
\hline Compound & ${ }^{1} \mathrm{H}$ NMR $\left(\mathrm{CD}_{3} \mathrm{CN}, \mathrm{ppm}\right)$ & ${ }^{13} \mathrm{C}$ NMR $\left(\mathrm{CD}_{3} \mathrm{CN}, \mathrm{ppm}\right)$ \\
\hline HA & $\begin{array}{c}\delta 5.36\left(\mathrm{br}, \mathrm{H}_{\mathrm{d}}\right), 4.48\left(\mathrm{~s}, \mathrm{H}_{\mathrm{a}}\right), 3.84 \\
\left(\mathrm{t}, \mathrm{H}_{\mathrm{c}}\right), 3.08\left(\mathrm{t}, \mathrm{H}_{\mathrm{b}}\right)\end{array}$ & $\delta 80.8\left(\mathrm{C}_{\mathrm{a}}\right), 65.0\left(\mathrm{C}_{\mathrm{c}}\right), 48.2\left(\mathrm{C}_{\mathrm{b}}\right)$ \\
\hline $\mathbf{B A}$ & $\begin{array}{c}\delta 3.74\left(\mathrm{t}, \mathrm{H}_{\mathrm{c}}\right), 3.65\left(\mathrm{~s}, \mathrm{H}_{\mathrm{a}}\right), 2.47 \\
\left(\mathrm{t}, \mathrm{H}_{\mathrm{b}}\right)\end{array}$ & $\delta 79.6\left(\mathrm{C}_{\mathrm{a}}\right) 66.3\left(\mathrm{C}_{\mathrm{c}}\right), 51.6\left(\mathrm{C}_{\mathrm{b}}\right)$ \\
\hline PPA & $\begin{array}{c}\delta 7.52\left(\mathrm{~m}, \mathrm{H}_{\mathrm{h}}\right) 7.42\left(\mathrm{tt}, \mathrm{H}_{\mathrm{j}}\right), 7.38 \\
\left(\mathrm{~m}, \mathrm{H}_{\mathrm{i}}\right), 5.36\left(\mathrm{br}, \mathrm{H}_{\mathrm{l}}\right)\end{array}$ & $\begin{array}{c}\delta 160.2\left(\mathrm{C}_{\mathrm{k}}\right) 133.2\left(\mathrm{C}_{\mathrm{h}}\right) 130.5\left(\mathrm{C}_{\mathrm{j}}\right), 129.7 \\
\left(\mathrm{C}_{\mathrm{i}}\right), 122.4\left(\mathrm{C}_{\mathrm{g}}\right) 87.0\left(\mathrm{C}_{\mathrm{e}}\right), 80.2\left(\mathrm{C}_{\mathrm{f}}\right)\end{array}$ \\
\hline PGA & $\begin{array}{c}\delta 7.45\left(\mathrm{~m}, \mathrm{H}_{\mathrm{h}}\right) 7.36\left(\mathrm{~m}, \mathrm{H}_{\mathrm{i}} / \mathrm{H}_{\mathrm{j}}\right) \\
\delta 3.74\left(\mathrm{t}, \mathrm{H}_{\mathrm{c}}\right), 3.65\left(\mathrm{~s}, \mathrm{H}_{\mathrm{a}}\right), 2.76 \\
\left(\mathrm{t}, \mathrm{H}_{\mathrm{b}}\right)\end{array}$ & $\begin{array}{c}\delta 132.6\left(\mathrm{C}_{\mathrm{h}}\right) 129.7\left(\mathrm{C}_{\mathrm{i}}\right), 129.6\left(\mathrm{C}_{\mathrm{j}}\right), 123.6 \\
\left(\mathrm{C}_{\mathrm{g}}\right), 87.0\left(\mathrm{C}_{\mathrm{e}}\right), 84.3\left(\mathrm{C}_{\mathrm{f}}\right), 66.9\left(\mathrm{C}_{\mathrm{c}}\right), 52.7 \\
\left(\mathrm{C}_{\mathrm{b}}\right), 48.0\left(\mathrm{C}_{\mathrm{a}}\right)\end{array}$ \\
\hline
\end{tabular}

${ }^{a}$ All the peaks were assigned based on the 2D NMR analysis
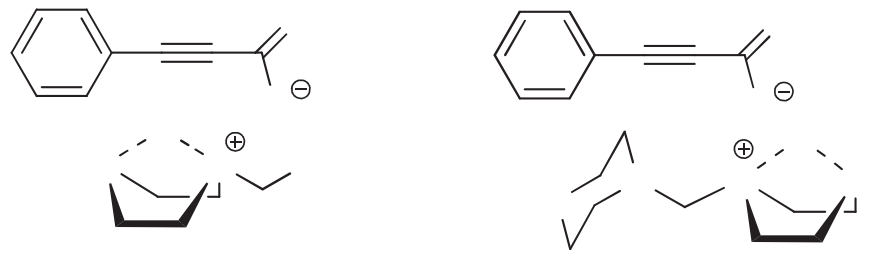

Figure 3. Proposed reaction intermediates $\mathbf{A}$ and $\mathbf{B}$.

The adduct HA-PPA formed from HA and PPA was characterized in the DOSY (diffusion-ordered spectroscopy). DOSY, an NMR spectroscopic technique, is used to analyze the individual components of a chemical mixture without prior physical separation. Highresolution DOSY methods utilize the molecular diffusion property. In a typical two-dimensional DOSY spectrum of a complex mixture, the chemical shift is shown on one axis, and the diffusion coefficient is shown on the other axis for each component. Smaller molecules show higher diffusion coefficients. If the reaction intermediates are present before proceeding to the final product, then DOSY is the method of choice to observe such a fleeting state when it is not 
possible, as in our case, to separate the reaction intermediates with chromatographic techniques such as HPLC. ${ }^{50}$

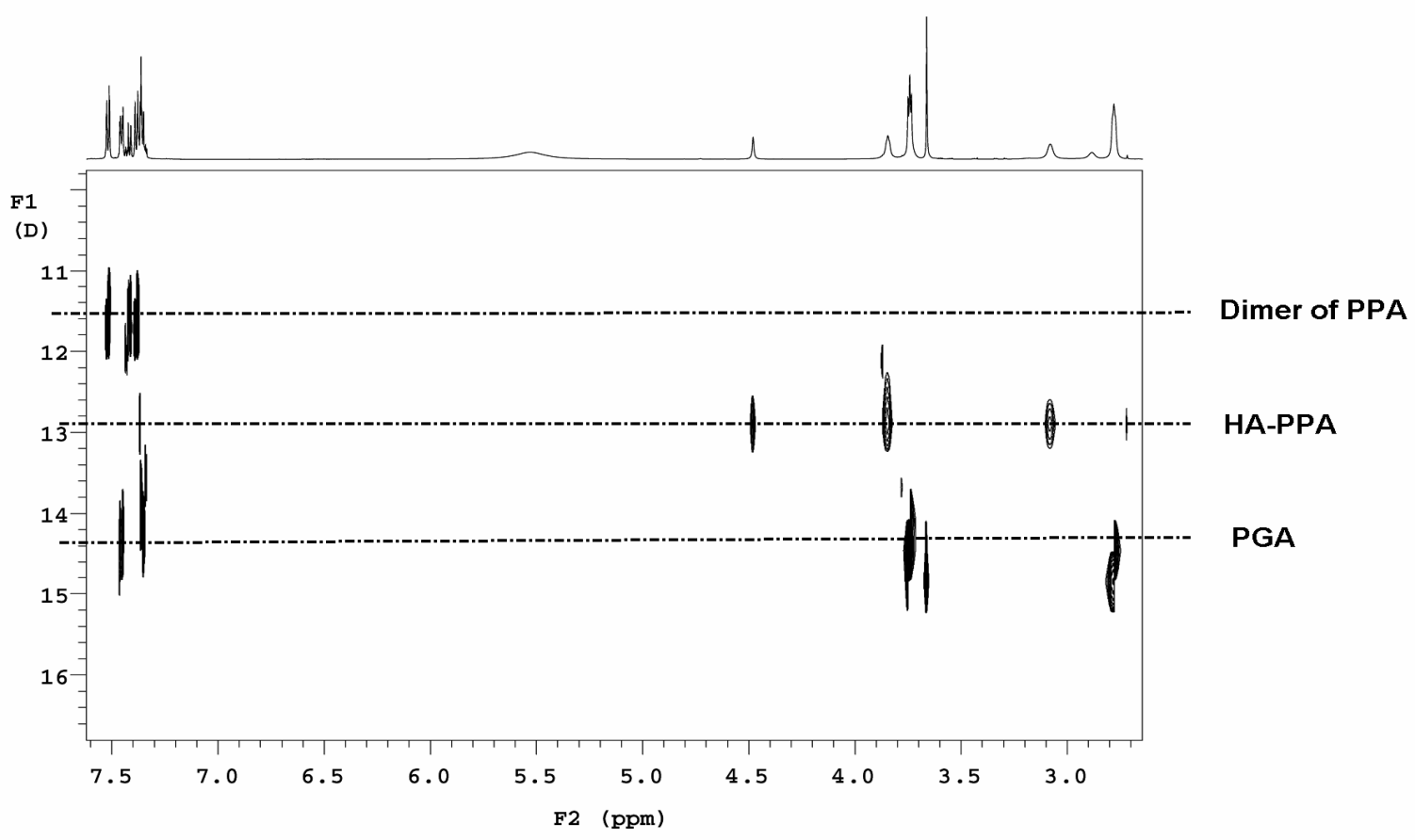

Figure 4. DOSY spectrum. DOSY analysis of a HA-BA-PPA mixture after $72 \mathrm{~h}$ of reaction at $65{ }^{\circ} \mathrm{C}$ in $\mathrm{CD}_{3} \mathrm{CN}$. Ordinate (F1 axis) represents the diffusion coefficient in $10^{10} \mathrm{~m}^{2} / \mathrm{s}$, and the other axis (F2 axis), abscissa, represents a regular one-dimensional ${ }^{1} \mathrm{H}$ NMR spectrum.

We were able to observe DOSY peaks, which can be attributed to the adducts of the starting materials, HA and PPA (denoted as HA-PPA, Figure 4). The three components of dimeric PPA, HA-PPA adduct, and PGA were observed in the order of diffusion coefficients according to the respective formula weights. The reaction intermediate, HA-PPA, is shown between the dimeric PPA, the largest formula weight compound with the lowest diffusion coefficient, and PGA, the smallest formula weight compound with a higher diffusion coefficient.

Moreover, the carbon peak of the carboxylic acid in free PPA shifted to high frequency value in the ${ }^{13} \mathrm{C}$ NMR when PPA was reacted with a mixture of paraformaldehyde and morpholine. As shown in Figure 5b, the carbonyl carbon of PPA was observed at $\delta 155.0$ ppm; however, it appeared at $\delta 160.2 \mathrm{ppm}$ in the reaction mixture. The alkynyl carbons shifted to low frequency value in the intermediate.

To follow the reaction profile, this reaction mixture was monitored at $65{ }^{\circ} \mathrm{C}$ by NMR. As shown in Figure 6, the integration values of proton peaks from HA and BA decreased, and those from product (PGA) increased with time. The proton peak of the carboxylic acid shifted to low frequency value, and its intensity decreased (see Supporting Information of Figure 3). 
a)
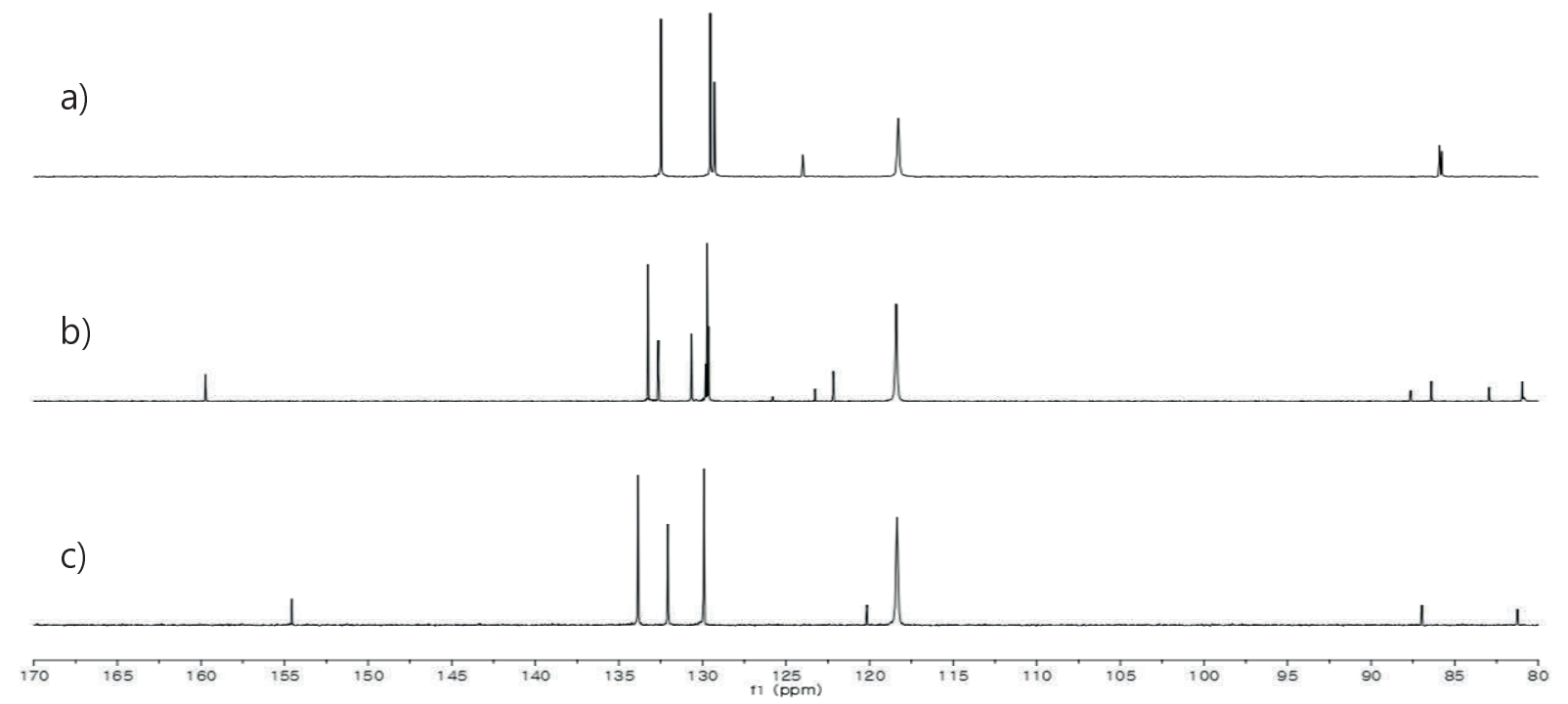

Figure 5. ${ }^{13} \mathrm{C}$ NMR data in $\mathrm{CD}_{3} \mathrm{CN}$. (a) PGA. (b) The reaction mixture of PPA, morpholine, and paraformaldehyde. (c) PPA.

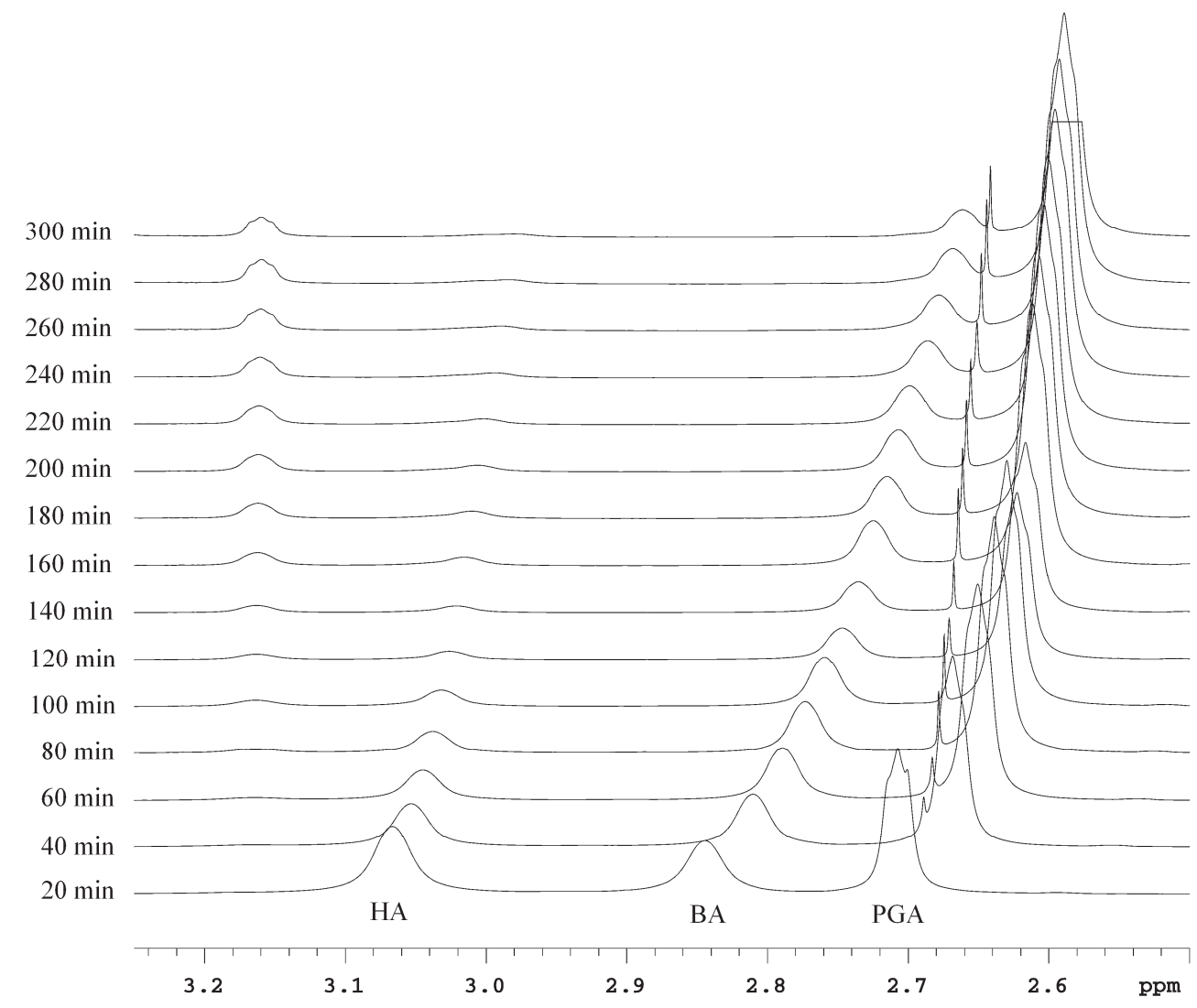

Figure 6. ${ }^{1} \mathrm{H}$ NMR data of the reaction mixture with PPA, paraformaldehyde and morpholine in $\mathrm{CD}_{3} \mathrm{CN}$. 
Based on these spectroscopic data, the reaction profile was plotted as shown in Figure 7. The yields were determined using the internal standard tetramethylsilane. When PPA was added to a mixture of paraformaldehyde and morpholine, $40 \%$ of PPA was converted to the desired product in $10 \mathrm{~min}$. As expected, the yield of propargylamine increased to $86 \%$ in $5 \mathrm{~h}$; however, PPA was not completely consumed.

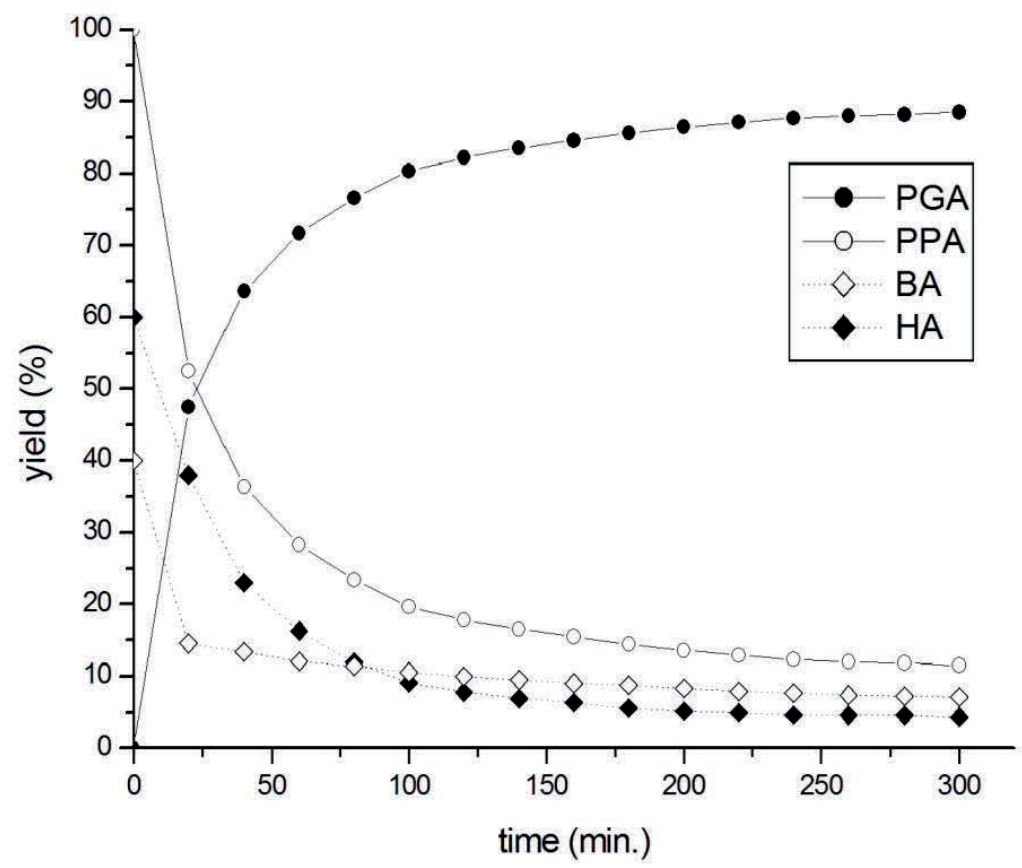

Figure 7. The reaction profile of the formation of PGA from PPA and paraformaldehyde and morpholine.

Based on these results, we proposed the reaction pathway as shown in Scheme 1. First, the reaction of paraformaldehyde and morpholine afforded the corresponding HA and BA. HA might be more reactive than $\mathbf{B A}$ in the decarboxylative coupling reaction. When the amount of morpholine was doubled, only $\mathbf{B A}$ was formed, and the desired product was obtained in a low yield (5\%). However, the iminium ion $\mathrm{C}$ which is derived from the HA was not detected in the reaction mixture by ${ }^{1} \mathrm{H}-{ }^{13} \mathrm{C}$ HMBC $2 \mathrm{D}$ NMR analysis. The interaction of HA with PPA produced the hydrogen-bonding adduct $\mathbf{A}$ and provided the desired propargylamine through decarboxylation (path $\mathbf{A}$ ). Path $\mathbf{A}$ is much favored than path $\mathbf{B}$, because adduct $\mathbf{B}$ was not detected in NMR. Although vinyl carbocation intermediate $\mathbf{D}$ proposed in the previous report ${ }^{47}$ was not detected in the reaction mixture by ${ }^{1} \mathrm{H}-{ }^{13} \mathrm{C}$ HMBC $2 \mathrm{D}$ NMR analysis, the NMR data analysis support that the decarboxylative coupling might proceed through the intermediate $\mathbf{A}$. However, we do not rule out the possible pathway $\mathbf{B}$ in which the intermediate $\mathbf{B}$ reacts so fast. 

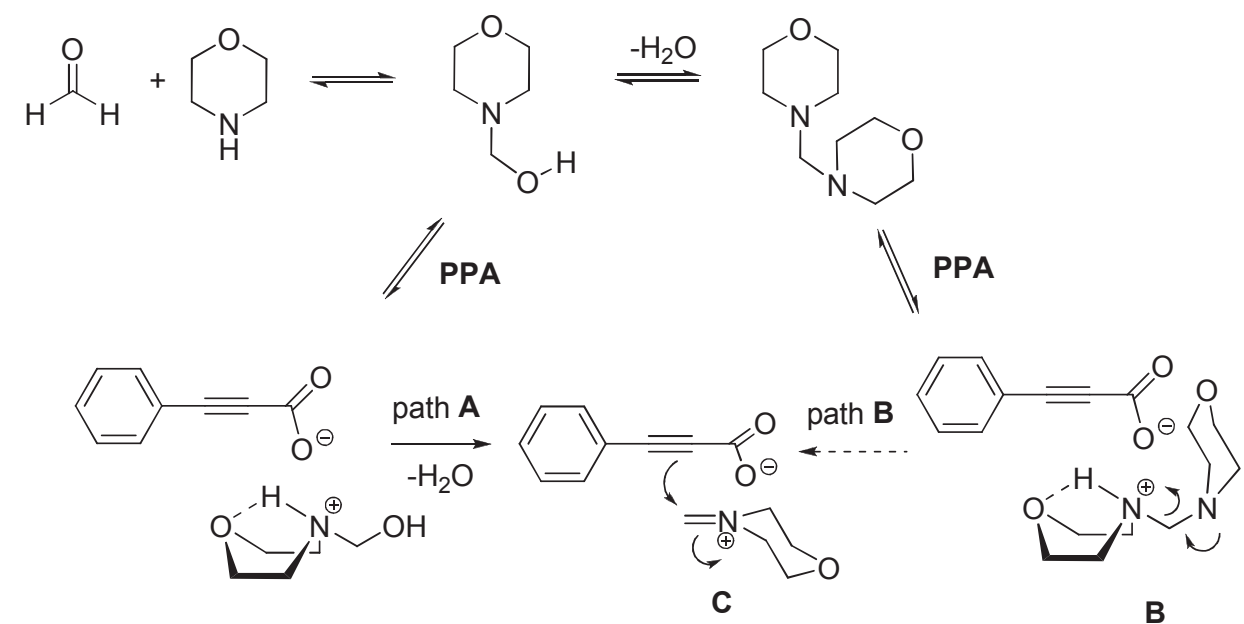

A

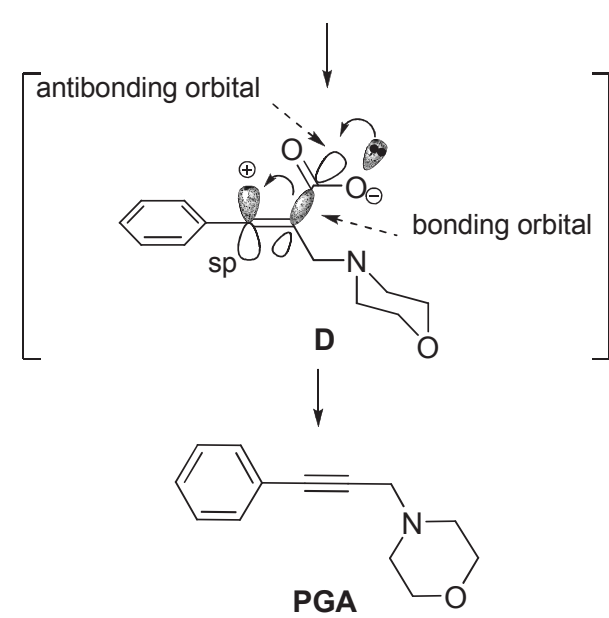

Scheme 1. Proposed pathway of the formation of PGA from decarboxylative coupling reaction.

\section{Conclusions}

In summary, the reaction pathway of the decarboxylative coupling reaction of PPA with paraformaldehyde and morpholine was studied by NMR spectroscopic analysis. Two aminals (HA and BA) were formed in the reaction mixture, and HA showed higher reactivity than BA. Moreover, the interactions of these aminals with PPA formed the corresponding adducts, which were identified by 2D NMR analysis and DOSY. The decarboxylative coupling reaction of HA and PPA may be the major pathway in the formation of propargylamines.

\section{Acknowledgements}

This research was supported by the National Research Foundation of Korea (NRF) grant funded by the Korean government (MSIP) (NRF-2014R1A2A1A 11050018, NRF-2015R1A4A 1041036). Spectral data were obtained at the Korea Basic Science Institute, Gwangju Branch. 


\section{References}

1. Rodríguez, N.; Goossen, L. J. Chem. Soc. Rev. 2011, 40, 5030. http://dx.doi.org/10.1039/c1cs15093f

2. Shang, R.; Liu, L. Sci. China. Chem. 2011, 54, 1670. http://dx.doi.org/10.1007/s11426-011-4381-0

3. Goossen, L. J.; Deng, G. Levy, L. M. Science 2006, 313, 662. http://dx.doi.org/10.1126/science.1128684

4. Moon, J.; Jeong, M.; Nam, H.; Ju, J.; Moon, J. H.; Jung, H. M.; Lee, S. Org. Lett. 2008, 10, 945.

http://dx.doi.org/10.1021/o1703130y

5. Moon, J.; Jang, M.; Lee, S. J. Org. Chem. 2009, 74, 1403. http://dx.doi.org/10.1021/jo802290r

6. Lim, J.; Choi, J.; Kim, H. -S.; Kim, I. S.; Nam, K. C.; Kim, J.; Lee, S. J. Org. Chem. 2016, $81,303$.

http://dx.doi.org/10.1021/acs.joc.5b02361

7. Huddleston, J. P.; Johnson, W. H. Jr.; Schroeder, G. K.; Whitman, C. P. Biochemistry 2015, 54,3009 . http://dx.doi.org/10.1021/acs.joc.5b02361

8. Hwang, J.; Choi, J.; Park, K.; Kim, W.; Song, K. H.; Lee, S. Eur. J. Org. Chem. 2015, 2235. http://dx.doi.org/10.1002/ejoc.201403644

9. Feng, H.; Jia, H.; Sun, Z. Adv. Synth. Catal. 2015, 357, 2447. http://dx.doi.org/10.1002/adsc.201500044

10. Pan, X.; Wan, X.; Yu, X.; Zhang, H.; Xie, W. Synthesis 2014, 46, 2057. http://dx.doi.org/10.1055/s-0033-1338622

11. Hwang, J.; Park, K.; Choe, J.; Min, H.; Song, K. H.; Lee, S. J. Org. Chem. 2014, 79, 3267. http://dx.doi.org/10.1021/j05003032

12. Hu, G.; Gao, Y.; Zhao, Y. Org. Lett. 2014, 16, 4464. http://dx.doi.org/10.1021/o1502009b

13. Kim, W.; Park, K.; Park, A.; Choe, J.; Lee, S. Org. Lett. 2013, 7, 1654. http://dx.doi.org/10.1021/o14004349

14. Kim, J.; Kang, D.; Yoo, E. J.; Lee, P. H. Eur. J. Org. Chem. 2013, 7902. http://dx.doi.org/10.1002/ejoc.201301441

15. Pérez, J. M.; Cano, R.; Yus, M.; Ramón, D. J. Synthesis 2013, 45, 1373. http://dx.doi.org/10.1055/s-0032-1316872

16. Park, K.; Lee, S. RSC Adv. 2013, 3, 14165. http://dx.doi.org/10.1039/c3ra41442f

17. Irudayanathan, F. M.; Oh, J.; Lee, S. Bull. Korean. Chem. Soc. 2015, 36, 1745. http://dx.doi.org/10.1002/bkcs.10348

18. Irudayanathan, F. M.; Noh, J.; Choi, J. Lee, S. Adv. Synth. Catal. 2014, 356, 3433. 
http://dx.doi.org/10.1002/adsc.201400451

19. Palani, T.; Park, K.; Song, K. H.; Lee, S. Adv. Synth. Catal. 2013, 355, 1160.

http://dx.doi.org/10.1002/adsc.201201106

20. Ziyaadini, M.; Maghsoodlou, M. T.; Hazeri, N.; Habibi-Khorassani, S. M. Monatsh. Chem. 2012, 143, 1681. http://dx.doi.org/10.1007/s00706-012-0743-3

21. Xu, M.; Kuang, C.; Wang, Z.; Yang, Q. Synlett 2010, 17, 2664.

22. Huleatt, P. B.; Khoo, M. L.; Chua, Y. Y.; Tan, T. W.; Liew, R. S.; Balogh, B.; Deme, R.; Gölöncsér, F.; Magyar, K.; Sheela, D. P.; Ho, H. K.; Sperlágh, B.; Mátyus, P.; Chai, C. L. L. J. Med. Chem. 2015, 58, 1400. http://dx.doi.org/10.1021/jm501722s

23. Ghashghaei, O.; Revés, M.; Kielland, N.; Lavilla, R. Eur. J. Org. Chem. 2015, 4383. http://dx.doi.org/10.1002/ejoc.201500502

24. Hase, S.; Kayaki, Y.; Ikariya, T. ACS Catal. 2015, 5, 5135. http://dx.doi.org/10.1021/acscatal.5b01335

25. Chachignon, H.; Scalacci, N.; Petricci, E.; Castagnolo, D. J. Org. Chem. 2015, 80, 5287. http://dx.doi.org/10.1021/acs.joc.5b00222

26. Yuan, R.; Lin, Z. ACS Catal. 2015, 5, 2866. http://dx.doi.org/10.1021/acscatal.5b00252

27. Yamamoto, Y.; Hayashi, H.; Saigoku, T.; Nishiyama, H. J. Am. Chem. Soc. 2005, 127, 10804. http://dx.doi.org/10.1021/ja053408a

28. Yu, P. H.; Davis, B. A.; Boulton, A. A. Biochem. Pharmacol. 1993, 46, 753. http://dx.doi.org/10.1016/0006-2952(93)90564-D

29. Yu, P. H.; Davis, B. A.; Boulton, A. A. J. Med. Chem. 1992, 35, 3705. http://dx.doi.org/10.1021/jm00098a017

30. Kim, Y.; Nakamura, H. Synlett 2012, 23, 1686. http://dx.doi.org/10.1055/s-0031-1290376

31. Murai, T.; Mutoh, Y.; Ohta, Y.; Murakami, M. J. Am. Chem. Soc. 2004, 126, 5968. http://dx.doi.org/10.1021/ja048627v

32. Fischer, C.; Carreira, E. M. Org. Lett. 2001, 3, 4319. http://dx.doi.org/10.1021/o1017022q

33. Imada, Y.; Yuasa, M.; Nakamura, I.; Murahashi, S.-I. J. Org. Chem. 1994, 59, 2282. http://dx.doi.org/10.1021/jo00088a004

34. Mandlimath, T. R.; Sathiyanarayanan, K. I. RSC Adv. 2016, 6, 3117. http://dx.doi.org/10.1039/C5RA20812B

35. Rubio-Pérez, L.; Iglesias, M.; Munárriz, J.; Polo, V.; Pérez-Torrente, J. J.; Oro, L. A. Chem. -Eur. J. 2015, 21, 17701. http://dx.doi.org/10.1002/chem.201502993

36. Kaur, S.; Kumar, M.; Bhalla, V. Chem. Commun. 2015, 51, 16327. 
http://dx.doi.org/10.1039/C5CC05752C

37. Silva, T. L. D.; Rambo, R. S.; Rampon, D. D. S.; Radatz, C. S.; Benvenutti, E. V.; qw

Russowsky, D.; Schneider, P. H. J. Mol. Catal. A. Chem. 2015, 399, 71.

http://dx.doi.org/10.1016/j.molcata.2015.01.021

38. Zhang, Y.; Li, P.; Wang, M.; Wang, L. J. Org. Chem. 2009, 74, 4364.

http://dx.doi.org/10.1021/jo900507v

39. Chen, H. -B.; Zhao, Y.; Liao, Y. RSC Adv. 2015, 5, 37737.

http://dx.doi.org/10.1039/C5RA04729C

40. Bhatte, K. D.; Sawant, D. N.; Deshmukh, K. M.; Bhanage, B. M. Catal. Commun. 2011, 16, 114.

http://dx.doi.org/10.1016/j.catcom.2011.09.012

41. Feiz, A.; Bazgir, A. Catal. Commun. 2016, 73, 88.

http://dx.doi.org/10.1016/j.catcom.2015.09.028

42. Wang, S.; He, X.; Song, L.; Wang, Z. Synlett 2009, 447.

43. Trivedi, M.; Singh, G.; Kumar, A.; Rath, N. P. Inorg. Chim. Acta 2015, 438, 255. http://dx.doi.org/10.1016/j.ica.2015.09.025

44. Yong, G.-P.; Tian, D.; Tong, H.-W.; Liu, S.-M. J. Mol. Cat. A Chem. 2010, 323, 40.

45. Sakaguchi, S.; Mizuta, T.; Furuwan, F.; Kubo, T.; Ishii, Y. Chem. Commun. 2004, 1638. http://dx.doi.org/10.1039/b404430d

46. Lim, J.; Park, K.; Byeun, A.; Lee, S. Tetrahedron Lett. 2014, 55, 4875. http://dx.doi.org/10.1016/j.tetlet.2014.05.134

47. Park, K.; Heo, Y.; Lee, S. Org. Lett. 2013, 15, 3322. http://dx.doi.org/10.1021/ol401358t

48. Rosenau, R.; Rotthast, A.; Kosma, P. Tetrahedron 2004, 60, 301. http://dx.doi.org/10.1016/j.tet.2003.11.015

49. Netscher, T.; Mazzini, F.; Jestin, R. Eur. J. Org. Chem. 2007, 1176. http://dx.doi.org/10.1002/ejoc.200600874

50. Johnson, C. S. Jr. Prog. Nucl. Magn. Reson. Spectrosc. 1999, 34, 203. http://dx.doi.org/10.1016/S0079-6565(99)00003-5 